\title{
Service learning in medical and nursing training: a randomized controlled trial
}

\author{
A. Y. M. Leung - S. S. C. Chan - C. W. Kwan - M. K. T. Cheung • \\ S. S. K. Leung $\cdot$ D. Y. T. Fong
}

Received: 23 April 2011/Accepted: 20 September 2011/Published online: 1 October 2011

(C) The Author(s) 2011. This article is published with open access at Springerlink.com

\begin{abstract}
The purpose of this study was to explore the long term effect of a service learning project on medical and nursing students' knowledge in aging and their attitudes toward older adults. A total of 124 students were recruited and then randomized to intervention group (IG) and control group (CG). A pre-and-post-intervention design measured students' knowledge in aging (using modified Palmore's Fact on Aging Quiz) and attitudes toward older adults (using Kogan's Old People Scale). A total of 103 students completed all the activities and questionnaires. After the intervention, there were significant differences between the IG and CG on Palmore's mental health $(\mathrm{MH})(P=.04)$, Palmore's total score $(P=.02)$ and Kogan's negative attitudes toward older adults $(P=.001)$. All students increased their positive attitude toward older adults after the intervention. However, both the IG and CG showed a decrease in positive attitudes 1 month after the interventon, and such decrease varied, depending on the programme which students attended. The current study showed that the 10-week service learning activities significantly increased medical and nursing students' overall knowledge of aging and their understanding of mental health needs in old age, and reduced their negative attitudes toward older adults. However, the effect is not long-lasting. On the other hand, its effect on positive attitudes toward older adults cannot be concluded. Periodic contacts with older adults via service learning activities may be needed to sustain attitude change toward older adults.
\end{abstract}

Keywords Service learning $\cdot$ Medical and nursing students $\cdot$ Older adults $\cdot$ Attitude · Knowledge about aging

A. Y. M. Leung $(\bowtie) \cdot$ S. S. C. Chan - M. K. T. Cheung · S. S. K. Leung · D. Y. T. Fong School of Nursing, Li Ka Shing Faculty of Medicine, The University of Hong Kong, 4th Floor, William Mong Block, Faculty of Medicine Building, 21 Sassoon Road, Pokfulam, Hong Kong, SAR, China

e-mail: angleung@hku.hk

A. Y. M. Leung

Sau Po Centre on Aging, The University of Hong Kong, Hong Kong, SAR, China

C. W. Kwan

Department of Statistics and Actuarial Science, The University of Hong Kong, Hong Kong, SAR, China 


\section{Introduction}

As the population is greying, members of the society need to understand older adults' needs and the challenges they encounter. Nurses and doctors are professionals who have frequent contacts with older adults, both in their work settings and in their own living environments. Efforts should therefore be made to build positive relationships between medical/nursing students and the older generation, and prepare these students for their roles as caregivers for the aged (Fitzgerald et al. 2003; Hweidi and Al-Obeisat 2006).

Service learning is one way to provide quality gerontological training to the next generation of health professionals. Service learning is an "educational experience in which students participate in an organised service activity that meets identified community needs and actively engages students in reflection to increase understanding of course content, provide broader appreciation of the discipline, and enhance students' sense of civic responsibility" (Brown and Roodin 2001). Thus service learning provides students opportunities to produce the best outcomes from volunteer service and to relate their experiences to their learning objectives (Johanson 2009). Through participation in service learning projects with the elderly, medical and nursing students are able to identify age-related changes and the needs of older adults, overcome current myths about aging and gain the confidence to communicate with older adults. Eventually, they develop self-efficacy to deal with older adults and a sense of civic responsibility for the aging population.

Service learning is more than simple voluntary service, or practica or internships (Brown and Roodin 2001); it requires students to participate, understand and reflect (Johanson 2009). Service learning components have been incorporated in some nursing curricula; examples include providing voluntary services in an orphanage in Mexico (Johanson 2009), or doing something like reading stories that can be done in 10-12 weeks and can make a difference to older adults (Kirkpatrick and Brown 2006). Students' perceptions and feelings about their experiences in service learning projects have been reported in qualitative studies (Kirkpatrick and Brown 2006; Clayton and Dilley 2009; Johanson 2009). However, quantitative data on the effectiveness of service learning in students' attitudes toward older adults or increasing their knowledge about aging have seldom been reported.

Given the lack of scientific evidence on intergenerational exchanges between the young generation and older adults in Chinese society, the study reported here evaluated a service learning project called "Generations as Partners in Education (GAPIE)" implemented in the Hong Kong Special Administrative Region of China in 2008. The project was guided by the definition of service learning (Brown and Roodin 2001) and social learning theory (Bandura 1986). From this perspective, learning, as a kind of behaviour, is influenced by personal factors such as self-efficacy and environmental factors such as feedback from teachers or others (Bandura 1986). Learning about aging issues and elders' needs takes place when medical and nursing students are provided with an appropriate environment and receive feedbacks from mentors. In this project, older adults acted as mentors to students and gave relevant information or feedback to the students. The study examined the effects of this service learning project on medical and nursing students' knowledge about aging and their attitudes toward older adults.

\section{Methods}

A randomised controlled trial design with pre-and-post-intervention measurements was used in the study. Medical and nursing students were randomised to an intervention group and a control group after recruitment. 
Sample and recruitment

Subjects were students from the Bachelor of Medicine and Bachelor of Surgery (MBBS) programme and the Bachelor of Nursing (BNurs) programme. Recruitment was done through email and internal poster circulation. Participation in this project was voluntary and there was no linkage to any academic courses in the medical and nursing training programmes. A total of 124 students were recruited and then randomized to intervention group and control group.

Older adults were recruited from two non-governmental organizations (NGOs), at monthly meetings and through poster circulation. The researcher introduced the aims and objectives of the project to older adults and explained that they would take the role of mentor to university students. Upon agreeing these arrangements, 62 older adults signed up for the project and agreed to act mentors to the students. They were informed that their participation was voluntary, and was not related to the services they received from the NGOs. A total of 48 older adults participated in the project. Older adults aged from 62 to 86 , and their mean age was 73.5 (S.D. $=5.5$ ). Most of them were females $(83 \%)$ and married $(64 \%)$. The majority $(68 \%)$ had completed primary education or had had no education. Only $10 \%$ had a diploma or degree. All were community-dwelling older adults with at least one type of chronic illness (such as hypertension, diabetes, etc.). One third of the older adults (34\%) had daily contact with younger generations, but $21 \%$ had either no contact or less than one contact with young generation per month. All participating students and older adults signed an informed consent form, and the project was approved by the University Institutional Review Board.

\section{Intervention}

The intervention consisted of three components: a half-day introductory workshop, a 10 -week interaction period and a half-day intergenerational sharing session. The half-day introductory workshop was organized to introduce the aims of this project and issues related to aging. In this workshop, the researcher and a social worker trained both the older adults and the students: they highlighted essential communication skills with the two generations, the role that each party should play in the project, and the potentially safe activities that they could plan together. In the subsequent 10 weeks, each pair of participants (one older adult and one student) met for 1-2 h per week. Students were encouraged to work with the older adults as partners to identify their learning objectives during this period. Topics such as age-related changes, the challenge of chronic illness in old age, and a healthy lifestyle in later life could be discussed. Each pair worked out their own activities so that they could participate together. The ultimate goal was to let students learn 'what the reality of aging is' and 'how their partners (older adults) lived with the reality'. After the 10 -week interactions, the intergenerational sharing session was organised for sharing experiences and feelings about the GAPIE activities.

Students who were randomized to the control group were paired up in groups of two and participated in a 10-week self-directed online learning programme on aging. They were encouraged to discuss issues of aging in an online platform, in groups of two. Before the start of the online learning programme, they participated in a half-day introductory workshop. At the end of the self-directed learning period, these students were invited to attend a half-day sharing session. The online learning programme could also be accessed by students in the intervention group. 
Measures

Demographic data, including age, gender, the programme being studied, the year of study, and experience in voluntary work were collected from students. Their knowledge about aging was measured by the modified 70-question Palmore's Facts on Aging Quiz (Lee et al. 2006). Their attitude toward older adults was measured by Kogan's Old People Scale (Lambrinou et al. 2005). Both measures were completed before and after the intervention.

Palmore's Facts on Aging Quiz is divided into three sections: elderly perceptions (EP), physical health $(\mathrm{PH})$ and mental health $(\mathrm{MH})$. Each section consists of 25 items. Total scores are calculated by adding up all the items. Taking into consideration the suitability of the statements in Hong Kong Chinese society, the scale was modified by deleting 5 culturesensitive items and was then validated (Lee et al. 2006). The reliability of the modified Palmore's scale in a Hong Kong Chinese population was 0.476 (Lee et al. 2006). Total scores on the modified scale range from 0 to 70 ; the scores on the EP subscale range from 0 to 25, scores on PH from 0 to 20, and scores on MH from 0 to 25 in the full scale (Lee et al. 2006). A higher score on each subscale denotes better knowledge of aging issues.

Kogan's Old People Scale (1961) is a 34-item scale with 17 items expressing negative sentiments about older people and another 17 items expressing positive sentiments about older people. Cronbach's alpha coefficients for the negative scale and the positive scale were 0.73 and 0.65, respectively (Lambrinou et al. 2005). Both the positive scores and negative scores range from 17 to 85 in the full scale (Lambrinou et al. 2005). A higher score on the positive scale designates a more favourable disposition toward older adults and a higher score on the negative scale denotes a more unfavourable disposition toward older adults.

Data analyses

The data were analyzed using the Statistical Package for the Social Sciences (SPSS) software verion 17. Descriptive statistics were used to compare the characteristics of the two groups of students. Differences in their characteristics were examined using Chi-square statistics for categorical variables and t-test for continuous variable. The interactive effect of the type of students on the intervention effects was also examined. When the interactive effect was not significant, the intervention effects were calculated by grouping the two types of students (medical and nursing students) together as one type. ANOVAs with repeated measures were employed.

\section{Results}

Sixty-two students were randomised to the intervention group (IG) and the control group (CG) respectively (Fig. 1). Some students dropped out after the intervention started. A total of 103 students completed all the activities and questionnaires. Table 1 shows the demographics (age, gender, year of study, and experience in voluntary work) of the participants in the two groups.

Before the intervention, there were no significant differences between the intervention and control groups in Palmore's total score [IG: mean (S.D.) 41.48 (3.01); CG: 42.85 (4.42)], or in scores on elderly perceptions (EP) [(IG: 14.85 (2.86); CG: 15.21 (2.96)], physical health (PH) [(IG: 11.39 (1.62); CG: 11.38 (1.74)] or mental health (MH) [(IG: 


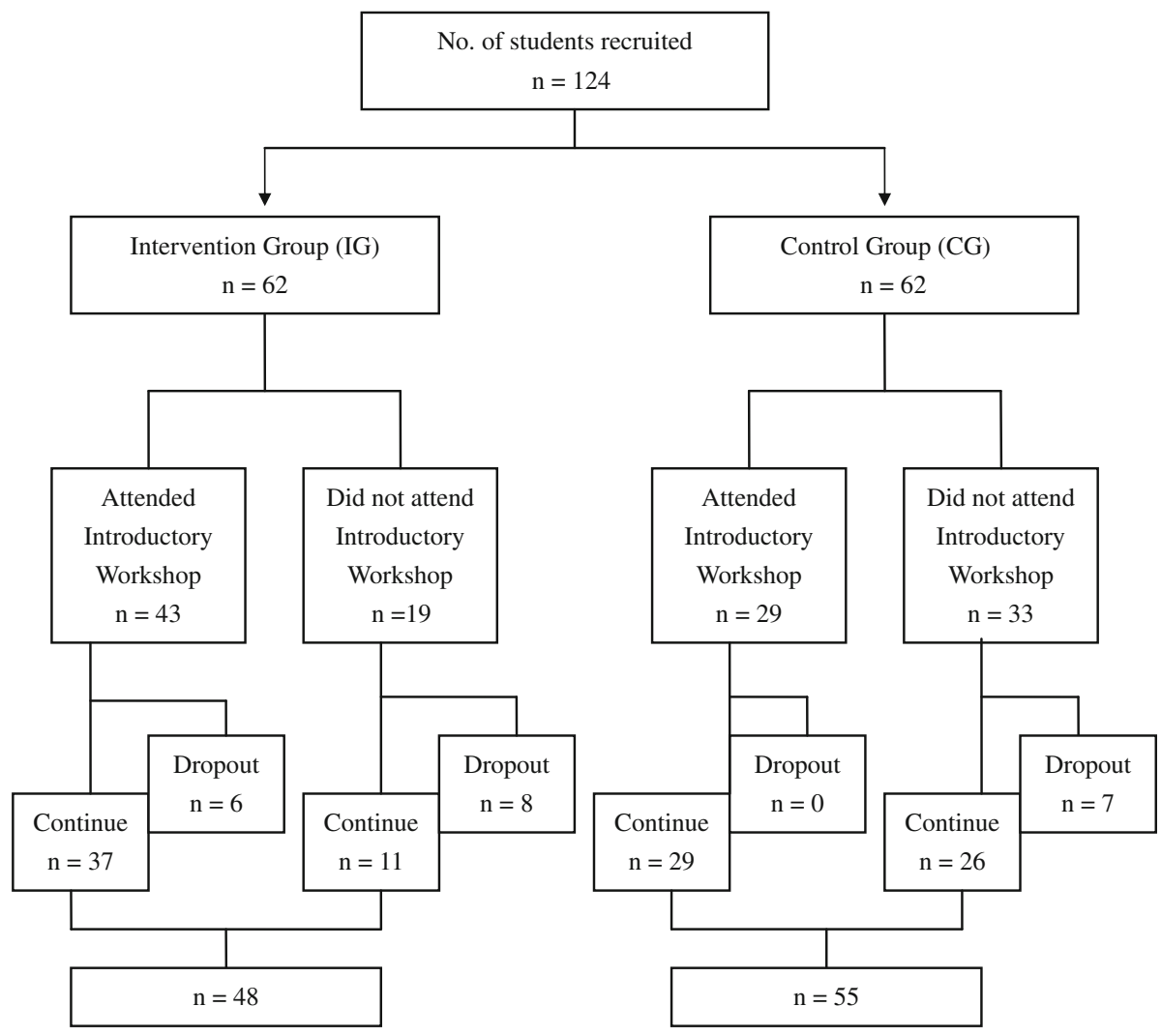

Fig. 1 Flowchart showing student recruitment and dropouts in the project

15.83 (2.64); CG: 16.26 (2.39)]. There were also no differences in the scores on positive attitudes [(IG: 45.04 (6.48); CG: 43.72 (5.84)] and negative attitudes toward older adults [(IG: 55.91 (4.80); CG: 53.85 (6.80)].

There was a significant interactive effect between group (control group vs. intervention group) and type of student (medical students vs. nursing students) on Kogan's positive attitudes toward older adults $(P=.03)$. No other significant differences were found between CG and IG $(P=.44)$ or between medical students and nursing students $(P=.64)$ (Table 2).

Since there was no interaction between the type of students and the groups on Palmore's total score $(P=.08)$, Palmore's elderly perceptions $(P=.41)$, Palmore's physical health $(P=.36)$, Palmore's mental mealth $(P=.08)$, and negative attitude toward older adults $(P=.23)$, we combined medical students and nursing students into one group and calculated the intervention effects. Table 3 shows the scores on all subscales of Palmore's scale and the score on Kogan's negative attitudes toward older adults. After the intervention, there were significant differences between the IG and CG on Palmore's mental health $(\mathrm{MH})(P=.04)$, Palmore's total score $(P=.02)$ and Kogan's negative attitudes toward older adults $(P=.001)$.

The IG showed a sharp and large increase in overall knowledge of aging, as measured by Palmore's total score, after the intervention (Fig. 2). One month later, although the IG 
Table 1 Demographics of the participants in Generations as Partners in Education (GAPIE) project

\begin{tabular}{|c|c|c|c|c|c|c|}
\hline & & \multirow{2}{*}{\multicolumn{2}{|c|}{$\frac{\text { Control }}{(n=55)}$}} & \multirow{2}{*}{\multicolumn{2}{|c|}{$\frac{\text { Intervention }}{(n=48)}$}} & \multirow[t]{3}{*}{$P$-value } \\
\hline & & & & & & \\
\hline & & $n$ & $\%$ & $n$ & $\%$ & \\
\hline \multicolumn{6}{|l|}{ Gender } & .47 \\
\hline Male & & 11 & 20.00 & 7 & 14.58 & \\
\hline Female & & 44 & 80.00 & 41 & 85.42 & \\
\hline \multicolumn{6}{|l|}{ Program of study } & .83 \\
\hline Medical & & 14 & 25.45 & 14 & 29.16 & \\
\hline Nursing & & 41 & 74.54 & 34 & 70.83 & \\
\hline \multicolumn{6}{|l|}{ Year of study } & .15 \\
\hline Year 1 & & 27 & 49.09 & 28 & 58.33 & \\
\hline Year 2 & & 5 & 9.09 & 8 & 16.67 & \\
\hline Year 3 & & 12 & 21.82 & 9 & 18.75 & \\
\hline Year 4 & & 11 & 20.00 & 3 & 6.25 & \\
\hline \multicolumn{6}{|l|}{ Volunteer work } & .05 \\
\hline Yes & & 35 & 64.81 & 22 & 45.83 & \\
\hline \multirow[t]{2}{*}{ No } & & 19 & 35.19 & 26 & 54.17 & \\
\hline & $M$ & & SD & $M$ & SD & \\
\hline Age & 21.00 & & 2.19 & 20.42 & 2.20 & .90 \\
\hline
\end{tabular}

Table 2 Comparing the scores in positive attitudes toward older adults between medical students and nursing students

\begin{tabular}{|c|c|c|c|c|c|c|c|}
\hline \multirow[t]{3}{*}{ Group } & \multirow[t]{3}{*}{ Program } & \multirow{3}{*}{$\begin{array}{l}\text { Pre-test } \\
(M \pm \mathrm{SD})\end{array}$} & \multirow{3}{*}{$\begin{array}{l}\text { 1st post-test } \\
(M \pm \mathrm{SD})\end{array}$} & \multirow{3}{*}{$\begin{array}{l}\text { 2nd post-test } \\
(M \pm \mathrm{SD})\end{array}$} & \multicolumn{3}{|l|}{$P$-value } \\
\hline & & & & & \multicolumn{2}{|l|}{ Within group } & \multirow[t]{2}{*}{$G \times T^{\mathrm{a}}$} \\
\hline & & & & & $\begin{array}{l}\text { Control } \\
\text { group } \\
\text { versus } \\
\text { intervention } \\
\text { group }\end{array}$ & $\begin{array}{l}\text { Medical } \\
\text { students } \\
\text { versus } \\
\text { nursing } \\
\text { students }\end{array}$ & \\
\hline \multirow[t]{3}{*}{ Control } & Medical & $42.00 \pm 4.72$ & $61.13 \pm 3.18$ & $40.63 \pm 8.80$ & .44 & .64 & .03 \\
\hline & Nursing & $44.16 \pm 6.09$ & $56.29 \pm 6.60$ & $48.87 \pm 8.33$ & & & \\
\hline & Total & $43.72 \pm 5.84$ & $57.28 \pm 6.34$ & $47.18 \pm 8.97$ & & & \\
\hline \multirow[t]{3}{*}{ Intervention } & Medical & $44.43 \pm 6.29$ & $56.14 \pm 5.24$ & $52.71 \pm 37.34$ & & & \\
\hline & Nursing & $45.31 \pm 6.75$ & $57.75 \pm 5.29$ & $42.81 \pm 7.09$ & & & \\
\hline & Total & $45.04 \pm 6.48$ & $57.26 \pm 5.21$ & $45.83 \pm 20.88$ & & & \\
\hline
\end{tabular}

a Interaction between group (control group and intervention group) and type of students (medical students and nursing students)

showed some decrease in Palmore's total score, the IG's score was still significantly higher than that of the CG (Fig. 2). For understanding of older adults' mental health, the IG showed an increasing trend after the intervention while the CG showed a decreasing trend 
Table 3 Comparing the knowledge of aging and negative attitudes toward older adults between intervention group and control group

\begin{tabular}{|c|c|c|c|c|c|}
\hline Knowledge of aging & Group & $\begin{array}{l}\text { Pre-test } \\
(M \pm \mathrm{SD})\end{array}$ & $\begin{array}{l}\text { 1st post-test } \\
(M \pm \mathrm{SD})\end{array}$ & $\begin{array}{l}\text { 2nd post-test } \\
(M \pm \mathrm{SD})\end{array}$ & $P$-value \\
\hline \multirow[t]{2}{*}{ Elderly perceptions } & Control & $15.21 \pm 2.96$ & $16.08 \pm 2.32$ & $15.21 \pm 2.89$ & .19 \\
\hline & Intervention & $14.85 \pm 2.86$ & $16.09 \pm 1.70$ & $15.61 \pm 1.99$ & \\
\hline \multirow[t]{2}{*}{ Physical health } & Control & $11.38 \pm 1.74$ & $12.44 \pm 2.14$ & $11.95 \pm 2.36$ & .97 \\
\hline & Intervention & $11.39 \pm 1.62$ & $12.52 \pm 1.97$ & $12.13 \pm 1.89$ & \\
\hline \multirow[t]{2}{*}{ Mental health } & Control & $16.26 \pm 2.39$ & $15.69 \pm 3.21$ & $15.23 \pm 3.56$ & .04 \\
\hline & Intervention & $15.83 \pm 2.64$ & $16.43 \pm 2.63$ & $17.17 \pm 1.50$ & \\
\hline \multirow[t]{2}{*}{ Palmore's total score } & Control & $42.85 \pm 4.42$ & $44.21 \pm 5.70$ & $42.38 \pm 6.60$ & .02 \\
\hline & Intervention & $41.48 \pm 3.01$ & $45.04 \pm 4.52$ & $44.91 \pm 3.66$ & \\
\hline \multirow[t]{2}{*}{ Negative attitudes } & Control & $53.85 \pm 6.80$ & $45.36 \pm 7.33$ & $55.38 \pm 7.41$ & .001 \\
\hline & Intervention & $55.91 \pm 4.80$ & $39.22 \pm 6.92$ & $57.96 \pm 5.49$ & \\
\hline
\end{tabular}

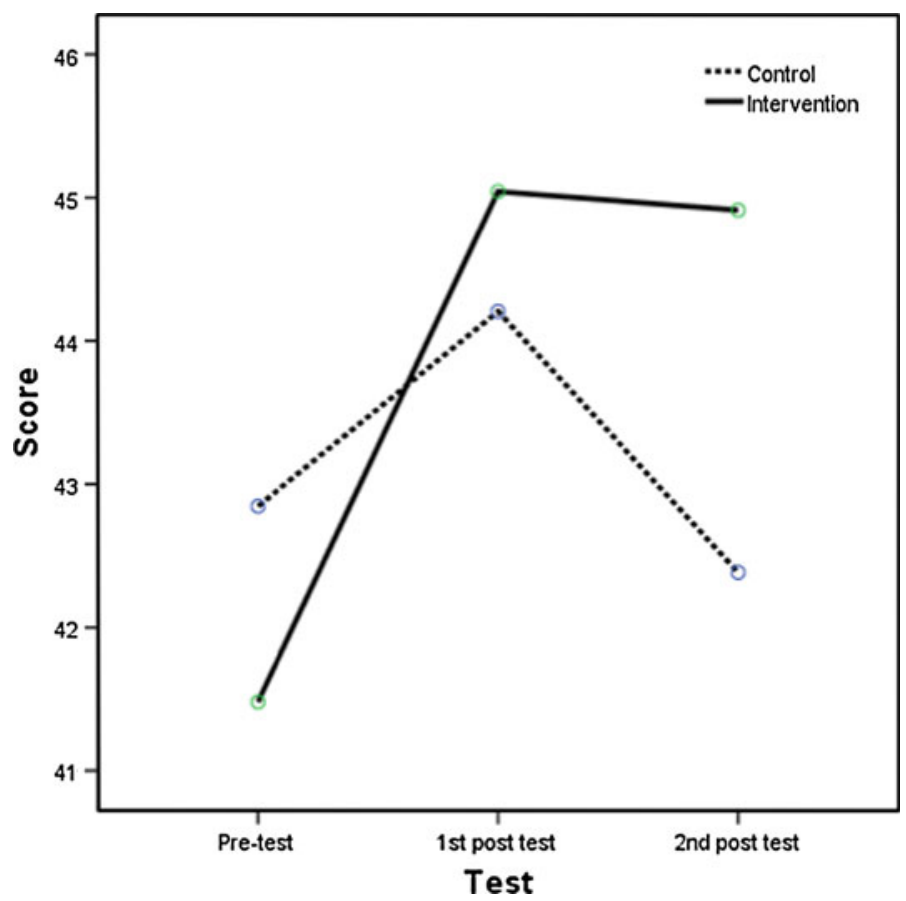

Fig. 2 Students' overall knowledge of aging (Palmore's Total Score)

(Fig. 3). The IG also showed more reduction in negative attitudes toward older adults than the CG, although both the IG and CG showed an increase in negative attitudes 1 month later (Fig. 4).

Figure 5 shows the change in positive attitudes toward older adults immediately after the intervention ( 1 st post test) and 1 month after the intervention ( 2 nd post test). For medical students, the IG had more positive attitudes toward older adults than the CG at 


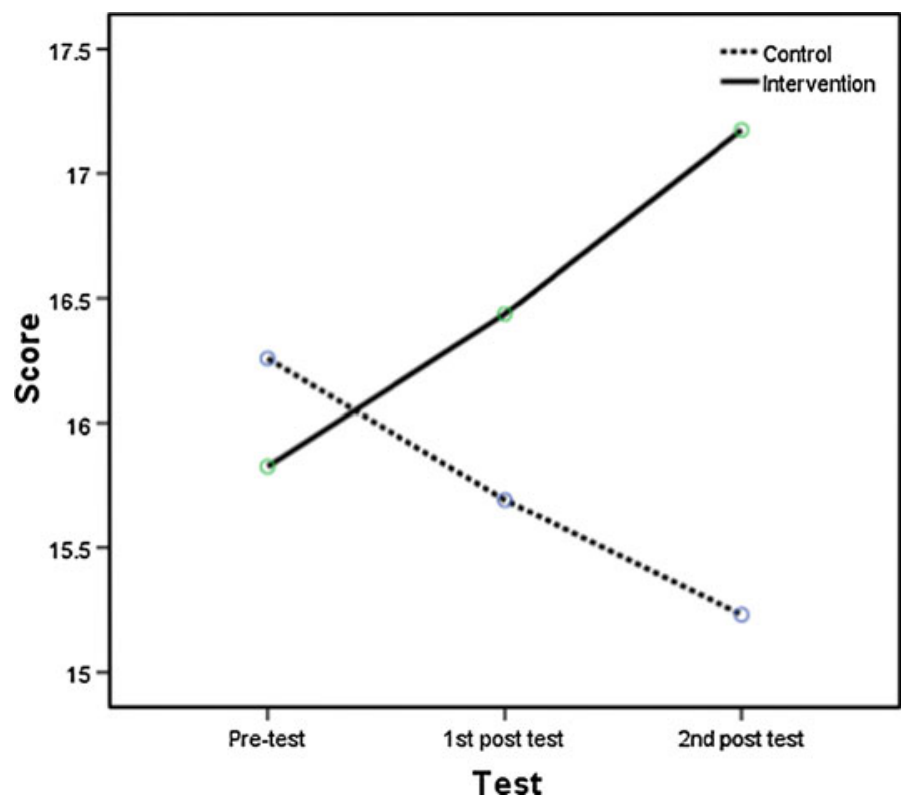

Fig. 3 Students' knowledge of older adults' mental health (Palmore's scale)

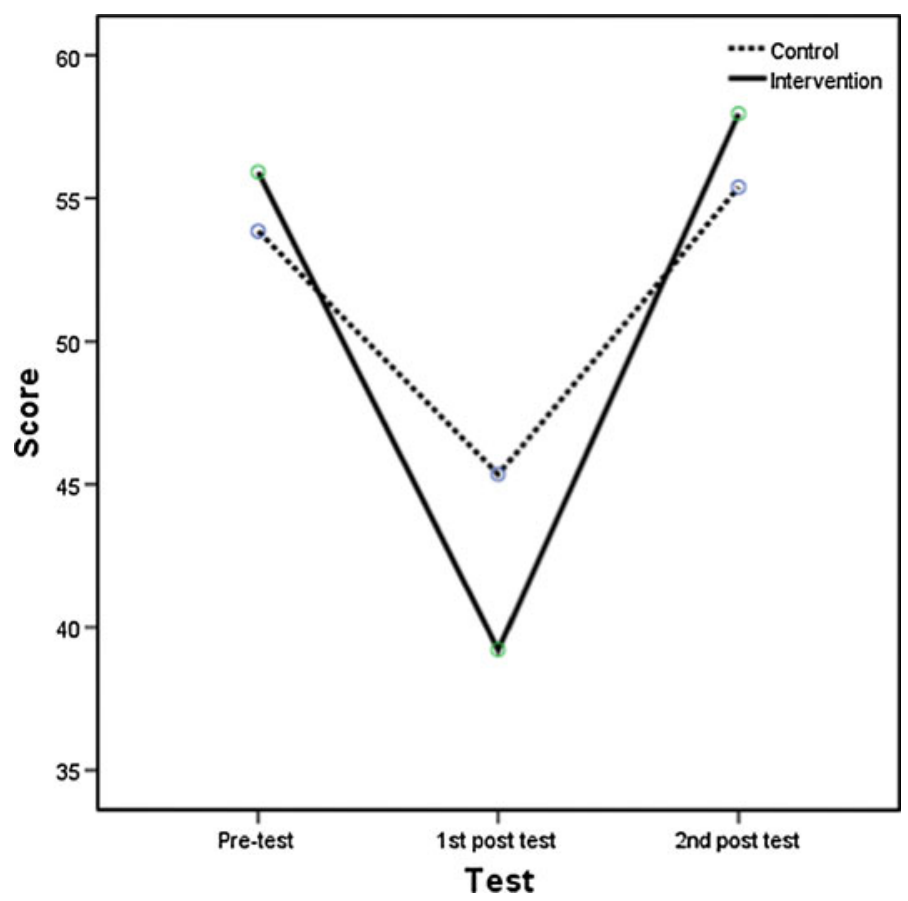

Fig. 4 Students' negative attitudes toward older adults (Kogan's scale) 


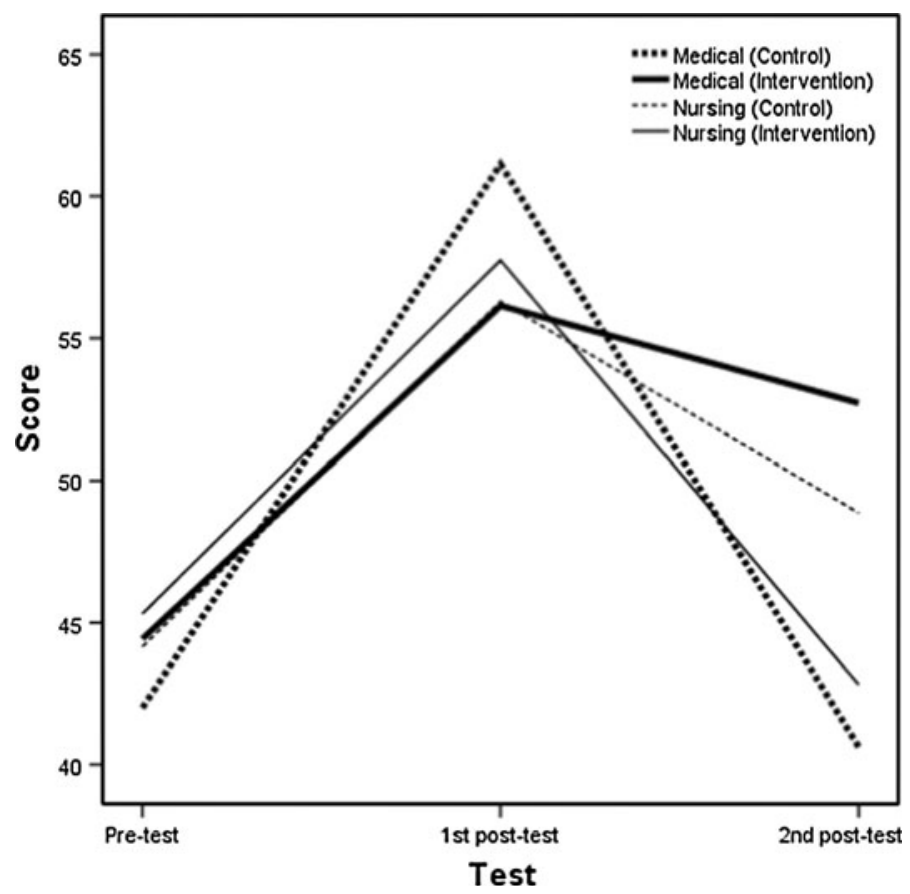

Fig. 5 Students' positive attitudes toward older adults (Kogan's scale)

baseline. But after the intervention, the medical student IG had less positive attitudes toward aging than the medical student CG. One month after the intervention, positive attitudes toward aging had decreased in both the medical student IG and the medical student CG, but the decrease was less in the IG than in the CG. Thus the medical student IG eventually had more positive attitudes toward aging than the CG. A different pattern was observed in the nursing groups. The nursing student IG had more positive attitudes than the CG before the intervention. Both the IG and CG increased their positive attitude scores after the intervention. However, 1 month after the intervention, both the IG and CG showed a decrease in positive attitudes, and the nursing student IG showed a greater decrease than the CG.

\section{Discussion}

The current study showed that the 10-week service learning activities in the GAPIE project significantly increased medical and nursing students' overall knowledge of aging and their understanding of mental health needs in old age, and reduced their negative attitudes toward older adults.

After the intervention, students in the IG had significantly more knowledge of aging than the CG. Although 1 month after the completion of the activities, IG students' overall knowledge of aging score dropped slightly, their understanding of aging was still significantly higher than that of students who had no interactions with community-dwelling older adults in the project. Inviting community-dwelling older adults to be the mentors of medical and nursing students appears to have been a good decision. When the medical/ 
nursing students had frequent contacts with older adults, they developed curiosity about aging issues and eventually developed an interest in learning more about aging. In this project, students learnt about real life experiences in old age: they talked to older adults, listened to older adults' explanations and descriptions of the way they were living in the community, and explored older adults' perceptions of illness and their coping strategies. These interactions served as an additional source of knowledge about aging and gerontological care. Thus the students in the intervention group learnt by their observations and interpretations of the information gathered through these service learning activities. This finding is consistent with the findings of a recent systematic review that explored the involvement of real patients in medical education (Jha et al. 2009). Students generally found that involving patients in their learning was stimulating and satisfying, and they demonstrated improvements in knowledge of disease and chronic illness conditions, and even about the social aspects of illness (Jha et al. 2009).

In the current study, students who interacted with older adults showed a better understanding of mental health needs in aging. The increase continued for 1 month after the completion of service learning activities. This may have been due to the fact that students' preconceived judgements about aging were challenged in the intervention. Some students were shocked to discover that older adults had to spend the whole day (starting from 7am) to attend a medical follow-up in the outpatient clinic in order to finally obtain their drugs from the dispenser at $3 \mathrm{pm}$. Interactions with older adults and participation in real life situations encouraged medical and nursing students to pay more attention to mental health care needs in aging. Other research has shown that community-dwelling older adults with chronic illnesses have greater perceived needs for mental health care (Garrido et al. 2009). Participation in the current service learning project increased our students' awareness of mental health care needs in the community.

The current study also showed that the 10-week out-of-classroom experiences significantly reduced students' negative attitudes toward older adults. After interacting with community-dwelling older adults, our students eventually found that many of their partners were still productive, independent, knowledgable and able to cope with the limitations in their daily living due to chronic illness and inevitable age-related changes. It is worth noting that changing one's attitude toward older adults is not an easy task. Without direct contact with older adults, students may have difficulty in imagining the realities of aging and understanding the actual needs of older adults in the community. Students in the intervention group seem to be better prepared than the control group to care for the aging population. Other authors have also found that service learning seems to leave students with personal insight and understanding of vulnerable groups, and to enrich their ability to perform population-based care (Clayton and Dilley 2009). Unfortunately, the current study found that the reduction in negative attitudes toward the elderly among the IG students did not last long; their negative attitudes increased 1 month after the completion of all the service learning activities. This may suggest that interacting with older adults gives students a clear and fresh reminder of the positive aspects of aging population. Thus their attitudes toward older adults changed. However, the learning experience is not strong enough to instill long term impact. When the students return back to normal daily lives in which they have limited exposure to older adults, they tend to forget and resume their negative attitudes. This suggests that the service learning activities had only a short-term impact on students' attitudes toward older adults and the sustainability of attitude change requires further work.

The effect of the GAPIE project on students' positive attitude toward older adults varied, depending on the programme which students attended. All students increased their 
positive attitude toward older adults after the intervention. One month later, those medical students who interacted with older adults in the project retained more positive attitudes than those who had no interactions. This seemed to indicate that the intervention was quite effective in sustaining improvements in students' positive attitudes toward older adults. However, nursing students performed differently. Nursing students in the intervention group experienced a significant decrease in positive attitude 1 month after the intervention. And their scores were even lower than the scores of those who had no interaction with older adults. Thus it cannot be definitively concluded that this service learning project affected students' positive attitudes toward older adults. After participating in the 10-week intervention, students attended a session where they shared their feelings and experiences. Many students expressed their appreciation for their partners (the older adults) who had actively engaged in the project and provided useful information about the realities of aging.

Periodic contacts with older adults via service learning activities may be needed to sustain attitude change toward older adults. As suggested by Collins et al. (2008), contacts between students and real patients could be extended to a period of 2 years and their meetings could be increased to 8 times over the 2 years. The service learning project described here was designed as a trial run for out-of-classroom experience in the new medical and nursing curriculum in Hong Kong. Consideration will be given to extending the duration of the service learning activities and involving students from other healthrelated discipline such as Pharmacy or Traditional Chinese Medicine in service learning in future.

The findings of this study suggest that medical and nursing educators need to design appropriate strategies to support students in learning gerontology in an innovative and interactive environment. Obviously, community-dwelling older adults are willing to share their views and wisdom with medical and nursing students. Opportunities should be developed to bring older adults and students together so that they can understand and appreciate the existence of their counterparts. This study found that through direct contacts, negative stereotypical attitudes about aging were reduced, and motivation to learn more about aging was fostered. In this project, we invited community-dwelling older adults who had at least one chronic illness to serve as partners. In future, we will consider inviting older adults with specific diseases such as cancer to discuss topics such as death preparation or life review.

This study also showed the importance of frequent interactions between generations. The more the younger generations interact with the older generations, the better the younger generations understand aging issues in general and the less negative their attitudes toward older adults.

\section{Limitations}

Although our results were promising, they need to be interpreted in light of some study limitations. Although Kogan's Scale has been shown to be a valid measure of attitudes toward older adults in the West, it may lack the sensitivity required to measure the same construct in Chinese culture. In addition, the sample was relatively small and a majority of the participants were females and nursing students. Increasing sample size and recruiting a gender-balanced or programme-balanced sample would improve the generalizability of the findings. Finally, when using a self-report questionnaire, people may give socially desirable answers to the questions, rather than the truth. In this study, we used the modified 70-question Palmore's Facts on Aging Scale to measure students' knowledge of aging. Its psychometric properties have been discussed by many researchers and some found its test- 
retest reliability to be uncertain (Unwin et al. 2008; Williams et al. 2007; Cowan et al. 2004; Lusk et al. 1995). Since no better scale for measuring knowledge of aging was available, Palmore's scale was used in the current study. Caution should be taken, however, in interpreting the results.

\section{Conclusions}

In conclusion, service learning was found to stimulate students to learn more about aging in general and rectify their stereotypical attitudes toward older adults. Educators and instructors who work with young health professionals need to be aware of the short-term effects of service learning activities on students' knowledge of aging in general and their longer term effects on students' knowledge of mental health care needs in the aging population. The knowledge and attitude gains are limited. This may suggest that service learning activities stimulate students' learning of aging issues and older adults' actual needs. However, when the students have less exposure to older adults, they tend to forget and resume their attitudes. Providing opportunities for medical and nursing students to interact with older adults is worthwhile and should be continued. In view of the limited evidence of the effectiveness of this programme, we recommend to conduct a cost/benefit analysis before undertaking further development.

Acknowledgments We wish to acknowledge the invaluable contribution of the students and older adults who participated in this study. Special thanks go to Connie Chiu, Pinky Jaw, Edward Lau for their kind support and assistance during data collection and preliminary analysis, and the anonymous reviewers for their thoughtful review and guidance. We would also like to thank St. James' Settlement and Sheng Kung Hui Council of Welfare for their kind support in assisting the coordination for older adults. This project was funded by KK Leung Teaching and Learning Grant 2006-2007, The University of Hong Kong (project code: 200701165012).

\section{Conflicts of interest None.}

Ethical approval Approval was obtained from the Institutional Review Board of the University of Hong Kong and Hospital Authority Hong Kong West Cluster.

Open Access This article is distributed under the terms of the Creative Commons Attribution Noncommercial License which permits any noncommercial use, distribution, and reproduction in any medium, provided the original author(s) and source are credited.

\section{Appendix 1: Modified Palmore's facts on aging quiz}

Please circle the appropriate number in the following scale to represent your own view.

\begin{tabular}{lcc}
\hline & True & False \\
\hline (B1) & $\begin{array}{c}\text { The majority of old people (age 65+) are senile (have defective memory, are } \\
\text { disoriented, or demented) }\end{array}$ & 2 \\
(B2) The five senses (sight, hearing, taste, touch, and smell) all tend to weaken in old age & 1 & 2 \\
(B3) The majority of old people have no interest in, nor capacity for, sexual relations & 1 & 2 \\
\hline
\end{tabular}


Appendix 1 continued

\begin{tabular}{|c|c|c|c|}
\hline & & True & False \\
\hline (B4) & Lung vital capacity tends to decline in old age & 1 & 2 \\
\hline (B5) & The majority of old people feel miserable most of the time & 1 & 2 \\
\hline (B6) & Physical strength tends to decline in old age & 1 & 2 \\
\hline (B7) & $\begin{array}{l}\text { At least one-tenth of the aged are living in long-stay institutions (such as nursing } \\
\text { homes, mental hospitals, homes for the aged, etc.) }\end{array}$ & 1 & 2 \\
\hline (B8) & Aged drivers have fewer accidents per driver than those under age 65 & 1 & 2 \\
\hline (B9) & Older workers usually cannot work as effectively as younger workers & 1 & 2 \\
\hline (B10) & Over three-fourths of the aged are healthy enough to carry out their normal activities & 1 & 2 \\
\hline (B11) & The majority of old people are unable to adapt to change & 1 & 2 \\
\hline (B12) & Old people usually take longer to learn something new & 1 & 2 \\
\hline (B13) & It is almost impossible for the average old person to learn something new & 1 & 2 \\
\hline (B14) & Older people tend to react slower than younger people & 1 & 2 \\
\hline (B15) & In general, old people tend to be pretty much alike & 1 & 2 \\
\hline (B16) & The majority of old people say they are seldom bored & 1 & 2 \\
\hline (B17) & The majority of old people are socially isolated & 1 & 2 \\
\hline (B18) & Older workers have fewer accidents than younger workers & 1 & 2 \\
\hline (B19) & Over $15 \%$ of the population are now age 65 or over & 1 & 2 \\
\hline (B20) & The majority of medical practitioners tend to give low priority to the aged & 1 & 2 \\
\hline (B21) & $\begin{array}{l}\text { The majority of old people have incomes below the poverty line (as defined by the } \\
\text { federal government) }\end{array}$ & 1 & 2 \\
\hline (B22) & $\begin{array}{l}\text { The majority of old people are working or would like to have some kind of work to } \\
\text { do (including housework and volunteer work) }\end{array}$ & 1 & 2 \\
\hline (B23) & Old people tend to become more religious as they age & 1 & 2 \\
\hline (B24) & The majority of old people say they are seldom irritated or angry & 1 & 2 \\
\hline (B25) & $\begin{array}{l}\text { The health and economic status of old people will be about the same or worse in the } \\
\text { next year (compared to younger people) }\end{array}$ & 1 & 2 \\
\hline (B26) & A person's height tends to decline in old age & 1 & 2 \\
\hline (B27) & $\begin{array}{l}\text { More older persons (age } 65 \text { or over) have chronic illnesses that limit their activity } \\
\text { than do younger persons }\end{array}$ & 1 & 2 \\
\hline (B28) & Older persons have more acute (short-term) illnesses than do younger persons & 1 & 2 \\
\hline (B29) & Older persons have more injuries in the home than younger persons & 1 & 2 \\
\hline (B30) & Older workers have less absenteeism than do younger workers & 1 & 2 \\
\hline (B31) & Men's life expectancy at age 65 is about the same as women's & 1 & 2 \\
\hline (B32) & The aged do not get their proportionate share of the nation's income & 1 & 2 \\
\hline (B33) & The aged have higher rates of criminal victimization than younger persons & 1 & 2 \\
\hline (B34) & The aged are more fearful of crime than are younger persons & 1 & 2 \\
\hline (B35) & The aged are the most law abiding of all adult age groups & 1 & 2 \\
\hline (B36) & There are about equal numbers of widows and widowers among the aged & 1 & 2 \\
\hline (B37) & More of the aged vote than any other age group & 1 & 2 \\
\hline (B38) & $\begin{array}{l}\text { There are proportionately more older persons in public office than in the total } \\
\text { population }\end{array}$ & 1 & 2 \\
\hline (B39) & $\begin{array}{l}\text { Participation in voluntary organizations (churches and clubs) tends to decline among } \\
\text { the healthy aged }\end{array}$ & 1 & 2 \\
\hline
\end{tabular}


Appendix 1 continued

\begin{tabular}{|c|c|c|c|}
\hline & & True & False \\
\hline (B40) & The majority of old people live alone & 1 & 2 \\
\hline$(\mathrm{B} 41)$ & The aged have a lower rate of poverty than the rest of the population & 1 & 2 \\
\hline (B42) & $\begin{array}{l}\text { The rate of poverty among aged blacks is about three times as high as among aged } \\
\text { whites }\end{array}$ & 1 & 2 \\
\hline (B43) & Older persons who reduce their activity tend to be happier than those who do not & 1 & 2 \\
\hline (B44) & $\begin{array}{l}\text { When the last child leaves home, the majority of parents have serious problems } \\
\text { adjusting to their "empty nest." }\end{array}$ & 1 & 2 \\
\hline (B45) & The proportion widowed among the aged is decreasing & 1 & 2 \\
\hline (B46) & $\begin{array}{l}\text { The majority of persons over } 65 \text { have some mental illness severe enough to impair } \\
\text { their abilities }\end{array}$ & 1 & 2 \\
\hline (B47) & $\begin{array}{l}\text { Cognitive impairment (memory loss, disorientation, or confusion) is an inevitable } \\
\text { part of the aging process }\end{array}$ & 1 & 2 \\
\hline (B48) & $\begin{array}{l}\text { If an older mental patient makes up false stories, it is best to point out that he or she } \\
\text { is lying, in order to reduce this behavior }\end{array}$ & 1 & 2 \\
\hline (B49) & The prevalence of neurosis and schizophrenia increases in old age & 1 & 2 \\
\hline$(\mathrm{B} 50)$ & Suicide rates increase with age for women past 45 & 1 & 2 \\
\hline (B51) & Suicide rates increase with age for men past 45 & 1 & 2 \\
\hline (B52) & $\begin{array}{l}\text { Fewer of the aged have mental impairments, when all types are added together, than } \\
\text { any other age groups }\end{array}$ & 1 & 2 \\
\hline (B53) & The primary mental health problem of older age is cognitive impairment & 1 & 2 \\
\hline (B54) & $\begin{array}{l}\text { Alzheimer's disease (progressive senile dementia) is the most common type of } \\
\text { chronic cognitive impairment among the aged }\end{array}$ & 1 & 2 \\
\hline (B55) & There is no cure for Alzheimer's disease & 1 & 2 \\
\hline (B56) & Most patients with Alzheimer's disease act the same way & 1 & 2 \\
\hline (B57) & Organic brain impairment is easy to distinguish from functional mental illness & 1 & 2 \\
\hline$(\mathrm{B} 58)$ & It is best not to look at mental patients when you are talking to them & 1 & 2 \\
\hline (B59) & $\begin{array}{l}\text { It is best to avoid talking to demented patients because it may increase their } \\
\text { confusion }\end{array}$ & 1 & 2 \\
\hline (B60) & $\begin{array}{l}\text { Demented patients should not be allowed to talk about their past, because it may } \\
\text { depress them }\end{array}$ & 1 & 2 \\
\hline$(\mathrm{B} 61)$ & The prevalence of cognitive impairment increases in old age & 1 & 2 \\
\hline (B62) & $\begin{array}{l}\text { Isolation and hearing loss are the most frequent causes of paranoid disorders in old } \\
\text { age }\end{array}$ & 1 & 2 \\
\hline (B63) & Poor nutrition may produce mental illness among the elderly & 1 & 2 \\
\hline (B64) & Mental illness is more prevalent among the elderly with less income and education & 1 & 2 \\
\hline (B65) & The majority of nursing home patients suffer from mental illness & 1 & 2 \\
\hline (B66) & The elderly have less sleep problems than younger persons & 1 & 2 \\
\hline (B67) & Major depression is more prevalent among the elderly than among younger persons & 1 & 2 \\
\hline (B68) & Widowhood is more stressful for older women than for younger women & 1 & 2 \\
\hline (B69) & More of the aged use mental health services than do younger persons & 1 & 2 \\
\hline (B70) & Psychotherapy is usually ineffective with older patients & 1 & 2 \\
\hline
\end{tabular}


Appendix 2: Attitudes toward older adults (Kogan's older people scale, 1961)

Please circle the appropriate number in the following scale to represent your own view.

\begin{tabular}{|c|c|c|c|c|c|c|}
\hline & & $\begin{array}{l}\text { Strongly } \\
\text { agree }\end{array}$ & Agree & Disagree & $\begin{array}{l}\text { Strongly } \\
\text { disagree }\end{array}$ & $\begin{array}{l}\text { No } \\
\text { comment }\end{array}$ \\
\hline (C1a) & $\begin{array}{l}\text { It would probably be better if most old } \\
\text { people lived in residential units with } \\
\text { people of their own age }\end{array}$ & 1 & 2 & 3 & 4 & 5 \\
\hline (C1b) & $\begin{array}{l}\text { It would probably be better if most old } \\
\text { people lived in residential units that also } \\
\text { housed younger people }\end{array}$ & 1 & 2 & 3 & 4 & 5 \\
\hline (C2a) & $\begin{array}{l}\text { There is something different about most } \\
\text { old people: it's hard to figure out what } \\
\text { makes them tick }\end{array}$ & 1 & 2 & 3 & 4 & 5 \\
\hline (C2b) & $\begin{array}{l}\text { Most old people are really not different } \\
\text { from anybody else: they are as easy to } \\
\text { understand as younger people }\end{array}$ & 1 & 2 & 3 & 4 & 5 \\
\hline (C3a) & $\begin{array}{l}\text { 3a Most old people get set in their ways } \\
\text { and are unable to change }\end{array}$ & 1 & 2 & 3 & 4 & 5 \\
\hline (C3b) & $\begin{array}{l}\text { More old people are capable of new } \\
\text { adjustments when the situation demands } \\
\text { it }\end{array}$ & 1 & 2 & 3 & 4 & 5 \\
\hline (C4a) & $\begin{array}{l}\text { Most old people would prefer to quit work } \\
\text { as soon as pensions or their children can } \\
\text { support them }\end{array}$ & 1 & 2 & 3 & 4 & 5 \\
\hline (C4b) & $\begin{array}{l}\text { Most old people would prefer to continue } \\
\text { working just as long as they possibly can } \\
\text { rather than be dependent on anybody }\end{array}$ & 1 & 2 & 3 & 4 & 5 \\
\hline (C5a) & $\begin{array}{l}\text { Most old people tend to let their homes } \\
\text { become shabby and unattractive }\end{array}$ & 1 & 2 & 3 & 4 & 5 \\
\hline (C5b) & $\begin{array}{l}\text { Most old people can generally be counted } \\
\text { to maintain a clean, attractive home }\end{array}$ & 1 & 2 & 3 & 4 & 5 \\
\hline (C6a) & $\begin{array}{l}\text { It is foolish to claim that wisdom comes } \\
\text { with old age }\end{array}$ & 1 & 2 & 3 & 4 & 5 \\
\hline (C6b) & $\begin{array}{l}\text { People grow wiser with the coming of old } \\
\text { age }\end{array}$ & 1 & 2 & 3 & 4 & 5 \\
\hline (C7a) & $\begin{array}{l}\text { Old people should have more power in } \\
\text { business and politics }\end{array}$ & 1 & 2 & 3 & 4 & 5 \\
\hline (C7b) & $\begin{array}{l}\text { Old people have too much power in } \\
\text { business and politics }\end{array}$ & 1 & 2 & 3 & 4 & 5 \\
\hline (C8a) & Most old people make one feel ill at case & 1 & 2 & 3 & 4 & 5 \\
\hline (C8b) & $\begin{array}{l}\text { Most old people are very relaxing to be } \\
\text { with }\end{array}$ & 1 & 2 & 3 & 4 & 5 \\
\hline (C9a) & $\begin{array}{l}\text { Most old people bore others by their } \\
\text { insistence on talking about the 'good old } \\
\text { days' }\end{array}$ & 1 & 2 & 3 & 4 & 5 \\
\hline
\end{tabular}


Appendix 2 continued

\begin{tabular}{|c|c|c|c|c|c|c|}
\hline & & $\begin{array}{l}\text { Strongly } \\
\text { agree }\end{array}$ & Agree & Disagree & $\begin{array}{l}\text { Strongly } \\
\text { disagree }\end{array}$ & $\begin{array}{l}\text { No } \\
\text { comment }\end{array}$ \\
\hline$(\mathrm{C} 9 \mathrm{~b})$ & $\begin{array}{l}\text { One of the most interesting and } \\
\text { entertaining qualities of most old people } \\
\text { is their accounts of their past } \\
\text { experiences }\end{array}$ & 1 & 2 & 3 & 4 & 5 \\
\hline (C10a) & $\begin{array}{l}\text { Most old people spend too much time } \\
\text { prying into the affairs of others and } \\
\text { giving unsought advice }\end{array}$ & 1 & 2 & 3 & 4 & 5 \\
\hline (C10b) & $\begin{array}{l}\text { Most old people tend to keep to } \\
\text { themselves and give advice only when } \\
\text { asked }\end{array}$ & 1 & 2 & 3 & 4 & 5 \\
\hline (C11a) & $\begin{array}{l}\text { If old people expect to be liked, their first } \\
\text { step is to try to get rid of their irritating } \\
\text { faults }\end{array}$ & 1 & 2 & 3 & 4 & 5 \\
\hline (C11b) & $\begin{array}{l}\text { When you think about it, old people have } \\
\text { the same faults as anybody else }\end{array}$ & 1 & 2 & 3 & 4 & 5 \\
\hline (C12a) & $\begin{array}{l}\text { In order to maintain a nice residential } \\
\text { neighbourhood, it would be best if too } \\
\text { many old people did not live in it }\end{array}$ & 1 & 2 & 3 & 4 & 5 \\
\hline (C12b) & $\begin{array}{l}\text { You can count on finding a nice } \\
\text { residential neighbourhood when there is } \\
\text { a sizeable number of old people living } \\
\text { in it }\end{array}$ & 1 & 2 & 3 & 4 & 5 \\
\hline (C13a) & $\begin{array}{l}\text { There are a few exceptions, but in general } \\
\text { most old people are pretty much alike }\end{array}$ & 1 & 2 & 3 & 4 & 5 \\
\hline (C13b) & $\begin{array}{l}\text { It is evident that most old people are very } \\
\text { different from one another }\end{array}$ & 1 & 2 & 3 & 4 & 5 \\
\hline (C14a) & $\begin{array}{l}\text { Most old people should be more } \\
\text { concerned with their personal } \\
\text { appearance, they're too untidy }\end{array}$ & 1 & 2 & 3 & 4 & 5 \\
\hline (C14b) & $\begin{array}{l}\text { Most old people seem to be quite clean } \\
\text { and neat in their personal appearance }\end{array}$ & 1 & 2 & 3 & 4 & 5 \\
\hline (C15a) & $\begin{array}{l}\text { Most old people are irritable, grouchy and } \\
\text { unpleasant }\end{array}$ & 1 & 2 & 3 & 4 & 5 \\
\hline (C15b) & $\begin{array}{l}\text { Most old people are cheerful, agreeable } \\
\text { and good humoured }\end{array}$ & 1 & 2 & 3 & 4 & 5 \\
\hline (C16a) & $\begin{array}{l}\text { Most old people are constantly } \\
\text { complaining about the behaviour of the } \\
\text { younger generation }\end{array}$ & 1 & 2 & 3 & 4 & 5 \\
\hline (C16b) & $\begin{array}{l}\text { One seldom bears old people complaining } \\
\text { about the behaviour of the younger } \\
\text { generation }\end{array}$ & 1 & 2 & 3 & 4 & 5 \\
\hline (C17a) & $\begin{array}{l}\text { Most old people make excessive demands } \\
\text { for love and reassurance }\end{array}$ & 1 & 2 & 3 & 4 & 5 \\
\hline (C17b) & $\begin{array}{l}\text { Most old people need no more love and } \\
\text { reassurance than anyone else }\end{array}$ & 1 & 2 & 3 & 4 & 5 \\
\hline
\end{tabular}




\section{References}

Bandura, A. (1986). Social foundations of thought and action: A social cognitive theory. Englewood Cliffs, N.J.: Prentice Hall.

Brown, L. H., \& Roodin, P. A. (2001). Service-learning in gerontology: An out-of-classroom experience. Educational Gerontology, 27, 89-103.

Clayton, L. H., \& Dilley, K. B. (2009). Service learning: population-focused nursing for the homeless at a soup kitchen. Nurses Education, 34, 137-139.

Collins, L. G., Arenson, C., \& Antony, R. (2008). Chronic illness care education: Longitudinal interprofessional mentor programme. Medical Education, 42, 1130-1131.

Cowan, D. T., Fitzpatrick, J. M., Roberts, J. D., \& While, A. E. (2004). Measuring the knowledge and attitudes of health care staff toward older people: Sensitivity of measuring instruments. Educational Gerontology, 30, 237-254.

Fitzgerald, J. T., Wray, L. A., Halter, J. B., Williams, B. C., \& Supiano, M. A. (2003). Relating medical students' knowledge, attitudes, and experience to an interest in geriatric medicine. The Gerontologist, 43, 849-855.

Garrido, M. M., Kane, R. L., Kaas, M., \& Kane, R. A. (2009). Perceived need for mental health care among community-dwelling older adults. Journal of Gerontology (B) Psychogical Science and Social Science, 64, 704-712.

Hweidi, I. M., \& Al-Obeisat, S. M. (2006). Jordanian nursing students' attitudes toward the elderly. Nurses Education Today, 26, 23-30.

Jha, V., Quinton, N. D., Bekker, H. L., \& Roberts, T. E. (2009). Strategies and interventions for the involvement of real patients in medical education: A systematic review. Medical Education, 43, 10-20.

Johanson, L. S. (2009). Service-learning; deepening students' commitment to serve. Journal of Christian Nursing, 26, 95-98.

Kirkpatrick, M. K., \& Brown, S. T. (2006). Leadership development in geriatric care through the intergeneration make a difference project. Nursing Education Perspectives, 27, 89-92.

Lambrinou, E., Sourtzi, P., Kalokerinou, A., \& Lemonidou, C. (2005). Reliability and validity of the Greek version of Kogan's old people scale. Journal of Clinical Nursing, 14, 1241-1247.

Lee, A. C. K., Wong, A. K. P., \& Loh, E. K. Y. (2006). Score in the Palmore's aging quiz, knowledge of community resources and working preferences of undergraduate nursing students toward the elderly in Hong Kong. Nurses Education Today, 26, 269-276.

Lusk, S. L., Williams, R. A., \& Hsuing, S. (1995). Evaluation of the facts on aging quizzes I \& II. Journal of Nursing Education, 34(7), 317-324.

Unwin, B. K., Unwin, C. G., Olsen, C., \& Wilson, C. (2008). A new look at an old quiz: Palmore's facts on aging quiz turns 30. Journal of the American Geriatrics, 56(11), 2162-2164.

Williams, B., Anderson, M. C., \& Day, R. (2007). Undergraduate nursing students knowledge of and attitude toward aging: Comparison of context-based learning and a traditional program. Journal of Nursing Education, 46(3), 115-120. 